\title{
A Rare Case of Waardenburg-Shah Syndrome without Family History
}

\author{
Aryani Atiyatul Amra*(i), Fithria Aldy (D), Barii Hafidh Pramono (iD \\ Department of Ophthalmology, Faculty of Medicine, Universitas Sumatera Utara, Medan, Indonesia
}

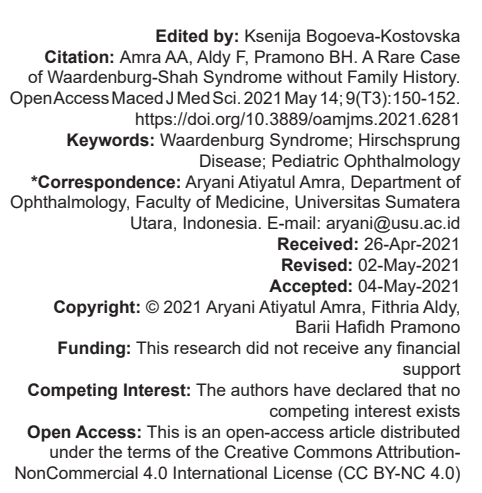

\begin{abstract}
BACKGROUND: Waardenburg syndrome (WS) is an uncommon genetic disorder that is most often characterized by pigmentary disturbance and lateral displacement of inner iris with variety of sensorineural deafness. The prevalence of this syndrome is about $1 / 42.000-1 / 50.000$ on population. There are approximately 48 cases of WS with Hirschsprung disease (HD) which were being reported up to 2002.

CASE REPORTS: A 7-year-old, Asian boy, routine patient of Pediatric-Surgery Department with HD was transferred from Pediatric-Surgery Department of Haji Adam Malik Hospital Medan to Ophthalmology Department of Universitas Sumatera Utara Hospital Medan with progressive abdominal distance and first ophthalmic evaluation. The patient is accompanied by a history of Hirschsprung disease, malnutrition, and sensorineural hearing loss. There was no family history being discovered. He is responding to visual command. Anterior segment examination showed that there were two different colors of iris - blue colored of the whole left iris and partial right iris. Fundoscopy showed pale retina on both eyes.

CONCLUSION: This patient is diagnosed with Waardenburg-Shah syndrome type IV. It is directly reality with a kind of other congenital disease like HD and no further treatment is needed.
\end{abstract}

\section{Introduction}

Waardenburg syndrome (WS) is an infrequent autosomal dominant condition mainly related to neural crest cells abnormalities [1]. WS often featured by Hirschsprung disease (HD); deafness; and depigmentation of hair (a white forelock), skin, and iris. Ophthalmic findings include telecanthus and dystopia canthorum [2]. The name of this syndrome is originated from the name of an ophthalmologist, namely, P. J. Waardenburg in 1947 who analyzed a syndrome with six clinical features, widely known as lateral changes of the medial canthus and lacrimal punctum, high nasal bridge, synophrys (connected eye brow, or unibrow), heterochromia iridis (complete, partial, or segmental), white forelock, and congenital deafness [3].

WS can affect both women and corresponding national races. Waardenburg in 1951 has observed patients with identical symptoms and then classified this particular syndrome as WS type 1. Aria in 1971 discovered a clinical picture of WS type 2, known as the complete clinical picture of type 1 without the existence of dystopia canthorum [3].

There are four subtypes WS according to the clinical manifestations [4]: Type I dystopia canthorum, broad nasal root, Type II without dystopia canthorum, Type III with upper limb defects, and Type IV with HD. Shah-WS
(SWS) is WS which is correlated to Hirschsprung's disease [5]. SWS is highly uncommon with $<80$ cases who were reported in the literature. This clinical feature often found in neonatal period with meconium resistance (more than $48 \mathrm{~h}$ ) or characterized by neonatal intestinal obstruction or constipation since birth although cases being presented beyond the neonatal period is recorded [6].

The prevalence of WS is 1/42.000-1/50.000 people. The most common types of WS are Types I and II, besides the rare one are Type III and IV. Type IV is unlikely with only 48 cases reported up to 2002 [7].

This problem potentially leads to a deliberation between the patients, and their parents generate further conflict and even domestic violence. This deliberateness in medicine practitioners might also cause unwanted interventions and existence of other unknown genetic diseases. We reported a 7-year-old boy who came to the clinic with clinical manifestation of WS with a history of HD.

\section{Case Report}

A 7-year-old, Asian boy, routine patient of Pediatric-Surgery Department with treated HD referred from Pediatric-Surgery Department of Haji Adam Malik Hospital 
Medan to Ophthalmology Department of Universitas Sumatera Utara Hospital Medan with progressive abdominal distance and first ophthalmic evaluation. The patient has a history of Hirschsprung disease (Figure 1), malnutrition, and sensorineural hearing loss. He was born of full-term normal vaginal delivery and meconium resistance (more than $48 \mathrm{~h}$ ). There was no family history being assessed.

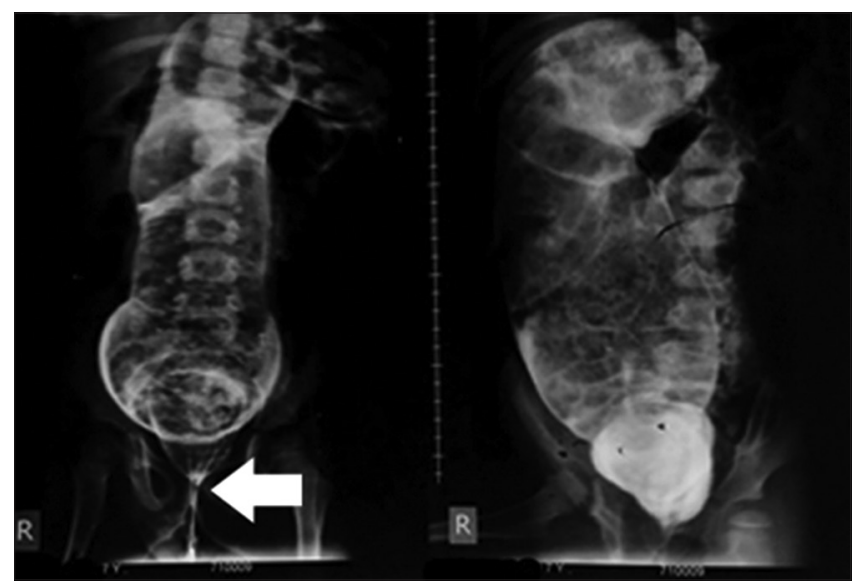

Figure 1: Hirschsprung, mouse tail appearance

On the general examination, the blue color of iris on the left eye and sectoral blue color of the iris was striking (Figure 2). The patient had white lock hair in his frontal areas. In this patient, we also discovered broad nasal bridges and Waardenburg Index (W-Index): $1.619(a=24, b=47, c=70)$ (Figure 2). The patient had sensorineural hearing impairment and malnutrition.

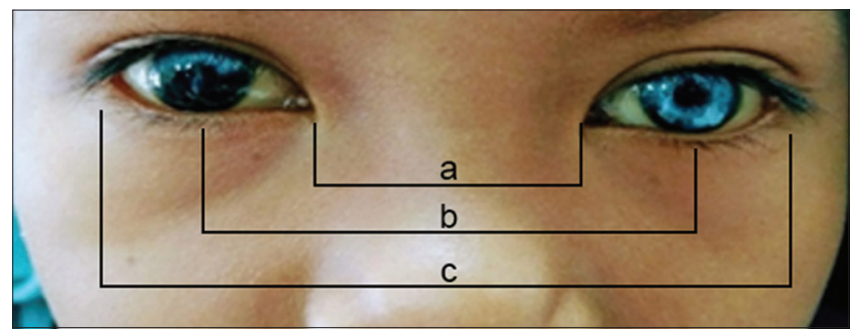

Figure 2: Sectoral heterochromia iridum $O D$, complete heterochromia iridum OS. a. ICD (inner canthal distance), b. IPD (interpupillary distance), c. OCD (outer canthal distance)

On ocular examination, he highly responded to visual command, the patient can follow the given instructions and follow the light. Anterior segment examination showed that two different colors of iris blue colored of the whole left iris and partial right iris. Fundoscopy showed pale retina of both eyes.

\section{Discussion}

WS constitutes of both ocular and extra ocular features [3]. Symptoms may vary from one patient to another, but there are major and minor criteria which directed the diagnose of WS such as follows [8]:
Note - W index: $\mathrm{W}$ index has to be measured (millimeters) which counts:

$$
\begin{gathered}
\text { X Formula }=\frac{2 a-(0.2119 c+3.909)}{c} \\
\text { Y Formula }=\frac{2 a-(0.2479 b+3.909)}{b} \\
W \text { Formula }=X+Y+\frac{a}{b}
\end{gathered}
$$

a: inner canthal distance; b: interpupillary distance; c: outer canthal distance [10].

The prevalence of congenital deafness in WS is about $2 \%$ [9]. This clinical manifestation is not generally the appearance of WS, but the emergence of sensorineural deafness on WS 1 and WS 2 is about $69 \%$ and $87 \%$ after excluding individuals who are accompanied by deafness. Depigmentation of hair is a different characterized. A white forelock is one of the most common cases (Figure 3) and it often occurred at an early life which then absence later in life, but this feature can appear again in young adult, or it might emerge on the primary time of any age. Farrer et al. also reported the appearance of white forelock with white hair on predominant scalp before the age of 30 . The other features that may also exist are hypoplasia of alae nasi and/or broad high nasal root [11].

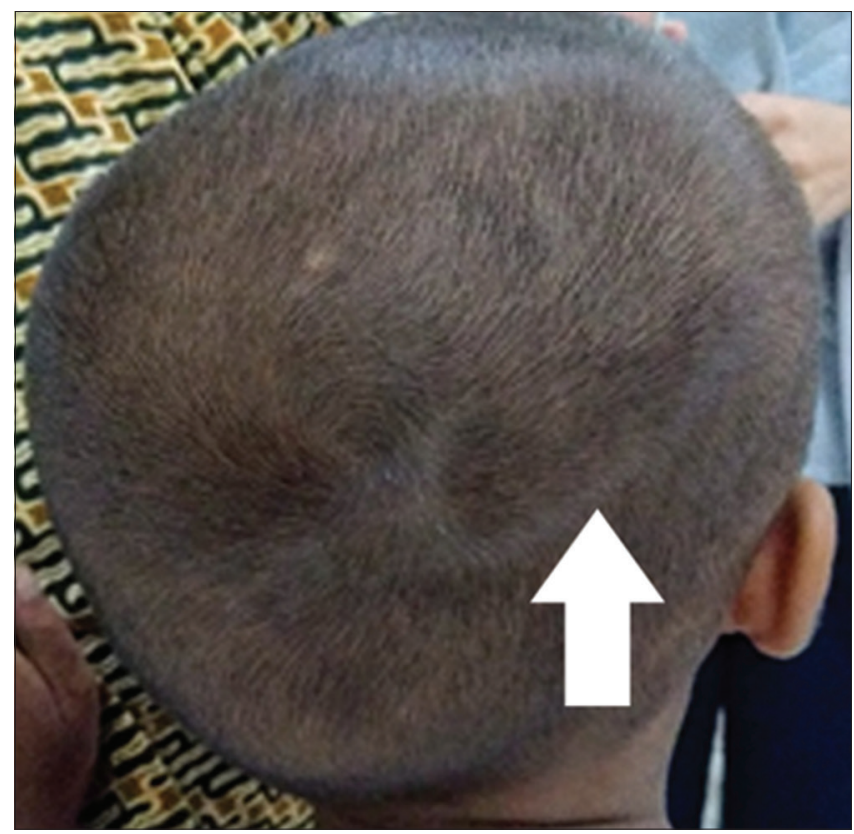

Figure 3: White lock hair

Other different features such as a cleft palate or lip, defects of neural tube, Sprengel shoulder (congenital displacement of upward scapular), congenital heart abnormalities, contractures, and hypoplasia of limb muscle (in WS3), and HD (mostly found on WS4) [12].

WS can be inherited through autosomal dominant with the majority of the subjects are obtained from affected parents. The minority of the patients do not have a family history and will be considered as a de novo 
case [13]. The disorder may sometimes is a spontaneous result from unknown reasons which indicates mutations in some individuals with no affected family of WS [14].

The diagnosis of WS can be established with a minimum criteria of two major or one major (Table 1). and two minor [15], [16]. According to Waardenburg diagnosis criteria, there are two main manifestations of major criteria during this syndrome, which are deafness and iris abnormal pigmentation. On the other hand, the other two minor features are prominent broad nasal root and white lock hair.

Table 1: Major and minor criteria for diagnosing Waardenburg syndrome

\begin{tabular}{|c|c|}
\hline Major criteria & Minor criteria \\
\hline Born deaf or hard of hearing & Patches of light or white skin \\
\hline Brilliant sapphire blue or two different color eyes & $\begin{array}{l}\text { Eyebrows extending toward } \\
\text { middle of the face }\end{array}$ \\
\hline White lock of hair on the forehead & Nose abnormalities \\
\hline Immediate family member & Premature graying of the hair \\
\hline Dystopia canthorum, $W$ index $>1.95$ (see Note $-W$ index) & \\
\hline
\end{tabular}

The WS type IV (Waardenburg-Shah syndrome [WSS]) classic presentations contain HD, sensorineural deafness, and depigmentation (on hair, skin, and iris) [5]. HD is strongly related to WS Type IV. The aganglionic megacolon is the most distinguishing feature [17].

Treatment may not be essential for some individuals, while others required treatment or surgery for other emerging abnormalities. WS does not necessarily affect the brain. Inheritance of types III and IV is more severe, but the practice of genetic counseling can help to minimize the risk of WS being transferred to a child [18].

\section{Conclusion}

To sum up, our represented case has some unique features of WS. In this case, there are two features of major criteria (deafness and iris abnormal pigmentation) and two minor criteria (prominent broad nasal root and white lock hair). In this case, we also found a history of HD that makes this condition even more special and recognized as WSS or also known as WS type IV. No treatments are required for this case, however, further research is needed to discover and understand more about this disorder.

\section{AQ3 References}

1. Boudjadi S, Chatterjee B, Sun W, Vemu P, Barr FG. The expression and function of PAX3 in development and disease. Gene. 2018;666:145-57. https://doi.org/10.1016/j. gene.2018.04.087

\section{PMid:29730428}

2. American Academy of Ophthalmology. Pediatric Ophthalmology and Strabismus. $6^{\text {th }}$ ed. San Fransisco: BCSC; 2020.

3. Kanal S, Optom B. Waardenburg syndrome a report of two familial case series. Optom Vis Perf. 2013;1(6):215-9.

4. Krishtul A, Galadari I. Waardenburg syndrome: Case report. Int J Dermatol. 2003;42:651-2. https://doi. org/10.1046/j.1365-4362.2003.01949_3.x

5. Shah KN, Dalal SJ, Desai MP, Sheth PN, Joshi NC, Ambani LM White forelock, pigmentary disorder of irides, and long segment Hirschsprung disease: Possible variant of Waardenburg syndrome. J Pediatr. 1981;99:432-5. https://doi.org/10.1016/ s0022-3476(81)80339-3

PMid:7264803

6. National Organization for Rare Disorders, Waardenburg Syndrome; 2017. Available from: https://www.rarediseases.org/ rare-diseases/waardenburg-syndrome. [Last accessed on 2017 Aug 26].

7. Egbalian, F. Waardenburg Shah syndrome: A case report and review of the literature. Iran J Pediatr. 2008;18(1):71-7.

8. Lahiri K, Lahiri B, Rai R, Malhotra N, Gahlowt P. Waardenburg syndrome Type 1: Case report. IOSR J Dent Med Sci. 2012;14(7):45-6.

9. Yang S, Cao J, Zhang R, Liu L, Liu X, Zhang X, et al. Nonsense mutations in the PAX 3 gene cause Waardenburg syndrome type I in two Chinese patients. Chin Med J (Engl). 2007;120(1):46-9. https://doi.org/10.1097/00029330-200701010-00009 PMid:17254487

10. Milunsky JM. Waardenburg syndrome Type I. In: Adam MP, Ardinger HH, Pagon RA., editors. GeneReviews ${ }^{\circledR}$. Seattle, WA: University of Washington, Seattle; 1993-2020.

11. Delleman JW, Hageman MJ. Heterogeneity in waardenburg syndrome. Am J Hum Genet. 1977;29(5):468-85.

PMid:331943

12. Read AP, Newton VE. Waardenburg syndrome. J Med Genet. 1997;34(8):656-65. PMid:9279758

13. Acluba KZ, Agahan AL. Blue-eyed Asian: A case report of Waardenburg syndrome type 1. Ophthalmic Res. 2016;5(2):1-5. https://doi.org/10.9734/or/2016/23417

14. National Organization for Rare Disorders, Waardenburg Syndrome; 2017. Available from: https://www.rarediseases.org/ rare-diseases/waardenburg-syndrome. [Last accessed on 2017 Aug 26].

15. Dumayas GL, Capo-Aponte JE. Case report: Waardenburg syndrome. Mil Med. 2015;180(3):e381-7. https://doi. org/10.7205/milmed-d-14-00430 PMid:25735036

16. Acluba KZ, Agahan AL. Blue-eyed Asian: A case report of Waardenburg syndrome Type 1. Ophthalmic Res. 2016;5(2):15. https://doi.org/10.9734/or/2016/23417

17. Şuhani RD, Şuhani MF, Muntean A, Mesaroş MF, Badea ME. Waardenburg syndrome type 2: An orthodontic perspective. Rom J Morphol Embryol. 2015;56 Suppl 2:879-83. PMid:26429191

18. Verheij JB, Sival DA, van der Hoeven JH, Vos YJ, Meiners LC Brouwer OF, et al. Shah-Waardenburg syndrome and PCWH associated with SOX10 mutations: A case report and review of the literature. Eur J Paediatr Neurol. 2006;10(1):11-7. https:// doi.org/10.1016/j.ejpn.2005.10.004

PMid:16504559 
Author Queries???

AQ3: Please note some duplicate reference $(6,14)(13,16)$ are found (highlighted). Please check and cite all references in chronological order 